\title{
3. GEOPHYSICAL MEASUREMENTS ACROSS THE EAST PACIFIC RISE IN THE VICINITY OF THE SIQUEIROS FRACTURE ZONE (SURVEY AREA PT-4)
}

\author{
William J. Ludwig and Philip D. Rabinowitz, Lamont-Doherty Geological Observatory of Columbia University, \\ Palisades, New York
}

In early 1976, a 35-day cruise aboard R/V Robert D. Conrad of the Lamont-Doherty Geological Observatory was devoted to a geophysical survey of two sites in the Pacific Ocean (Survey Areas PT-4 and PT-5) for the International Phase of Ocean Drilling program (IPOD).

PT-5 was surveyed between the Clarion and Molokai fracture zones near magnetic anomaly 13 on fast spreading Pacific crust near $21.5^{\circ} \mathrm{N}$ and $126.5^{\circ} \mathrm{W}$. The geophysical measurements and interpretation of the data for this area are given in Ludwig and Rabinowitz (in press).

PT-4 is located near the East Pacific Rise axis between the Siqueiros fracture zone at $8^{\circ} 15^{\prime} \mathrm{N}$ and the Clipperton fracture zone at $10^{\circ} \mathrm{N}$. The evolution of ocean crust in this area has been extensively discussed (Batiza et al., 1977; Rosendahl, 1976; Rosendahl et al., 1976; Orcutt et al., 1975, 1976). The survey was designated to obtain multichannel seismic measurements as well as additional underway geophysical measurements across the East Pacific Rise in the vicinity of proposed drill sites at PT-4.

The navigational course of R/V Robert D. Conrad in the vicinity of PT- 4 is given in Figure 1. Multichannel seismics and underway geophysical measurements were collected on three lines which traversed the strike of the East Pacific Rise (lines 17, 19 and 20) and on one line which was parallel to it (line 18).

Bathymetric, gravity, and magnetic profiles are given in Figures 2, 3, and 4, respectively. These data are shown plotted as profiles along ship tracks on the bathymetric base map given by Rosendahl (this volume). The sonobuoy results are shown as crustal sections in Figure 5. Multichannel seismic measurements processed on line 19 are given in Figure 6 (after Herron et al., 1978; Stoffa et al., in press).

\section{ACKNOWLEDGMENTS}

The IPOD site survey management, under subcontract with the Deep Sea Drilling Project (UC-NSF-C-482-2), supported the data acquisiton. Additional support came from the Office of Naval Research, contract N00014-75-C-0210.

\section{REFERENCES}

Batiza, R., Rosendahl, B. R., and Fisher, R. L., 1977. Evolution of ocean crust, Part III: Petrology and chemistry of basalts from the East Pacific Rise and Siqueiros Fracture Zone. J. Geophys. Res., v. 82, p. 265.

Herron, T. J., Ludwig, W. J., Stoffa, P. L., Kan, T. K., and Buhl, P., 1978. Structure of the East Pacific Rise Crest from multi-channel seismic reflection data. Ibid., v. 83, p. 798-804.

Ludwig, W. J. and Rabinowitz, P. D., in press. Geophysical characteristics of ocean crust: IPOD candidate site PT-5, Central Eastern Pacific Basin. Marine Geol.

Orcutt, J. A., Kennett, B. L., Dorman, L. M., 1976. Structure of the East Pacific Rise from an ocean bottom seismometer survey. Geophys. J. Roy. Astron. Soc., v. 45, p. 305-320.

Orcutt, J. A., Kennett, B. L., Dorman, L. M., and Prothero, W. A., 1975. Evidence for a low-velocity zone underlying a fast-spreading rise crest. Nature, v. 256, p. 475.

Rosendahl, B. R., 1976. Evolution of oceanic crust, Part II: Constraints, implications and inferences. J. Geophys. Res., v. 81 , p. 5305 .

Rosendahl, B. R., Raitt, R. W., Dorman, L. M., and Bibee, L. D., 1976. Evolution of oceanic crust, Part I: A physical model of the East Pacific Rise crest derived from seismic refraction data. Ibid., v. 81, p. 5294 .

Stoffa, P. L., Buhl, P., Herron, T. J., Kan, T. K., and Ludwig, W. J., in press. Mantle reflections beneath the crestal zone of the East Pacific Rise from multi-channel seismic data. Marine Geol. 


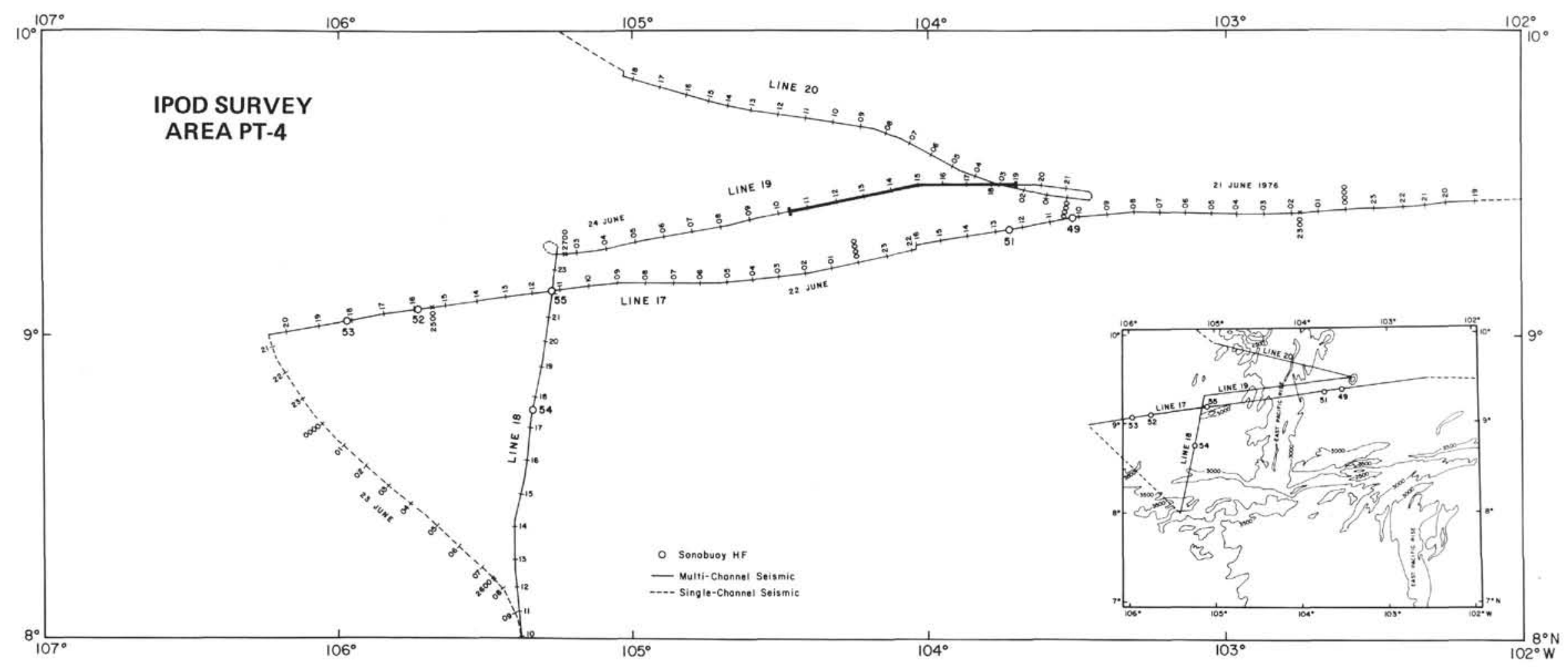

Figure 1. Navigational course of $R / V$ Conrad while covering IPOD Survey Area PT-4. Annotations are dates and hours. Location of multichannel seismic profile given in Figure 6 is shown by the bold section of line 19. 


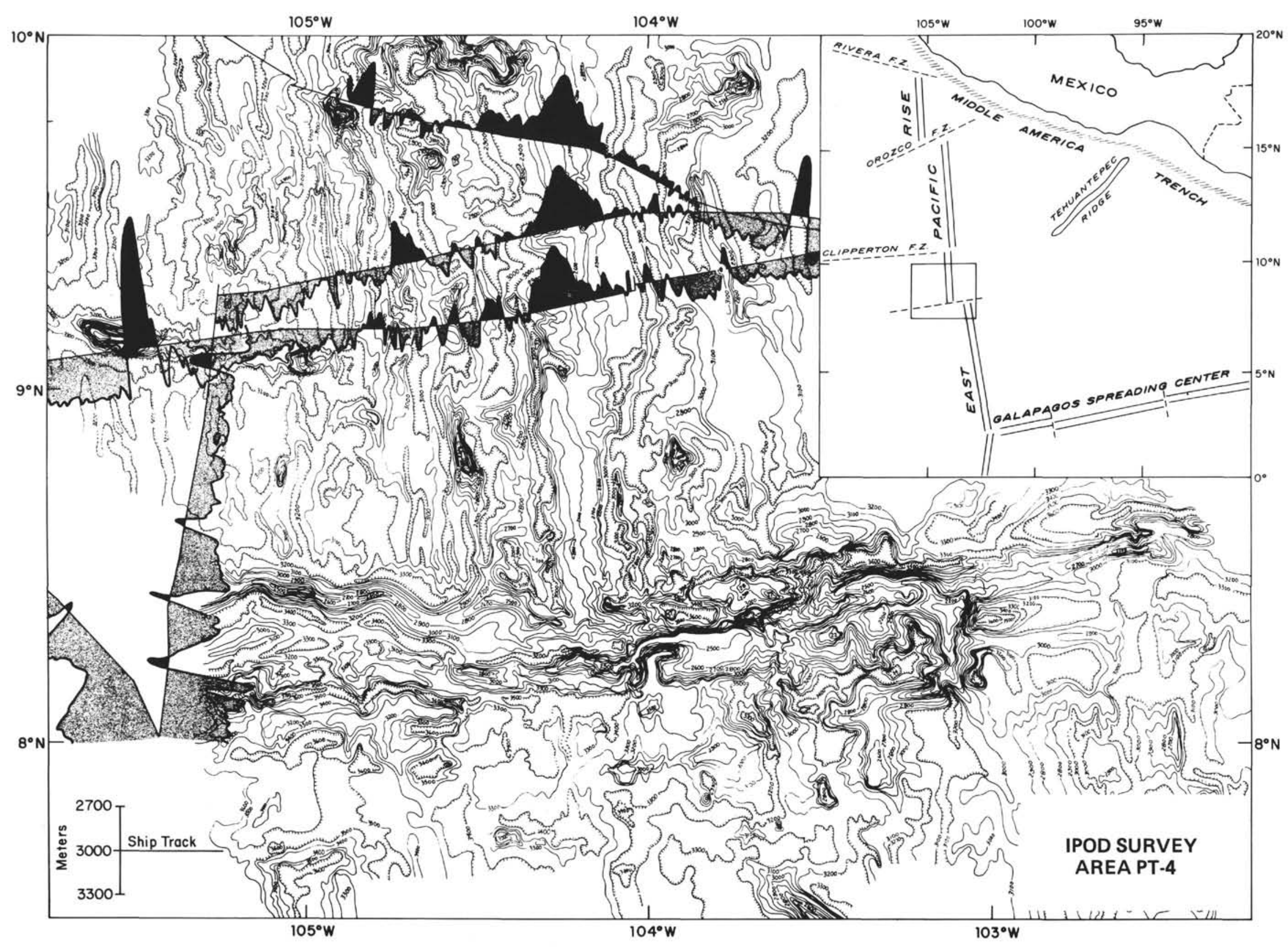

Figure 2. Bathymetry profiles along ship tracks. Base level (ship track) $=3000$ meters. Bathymetric contours from Rosendahl (this volume). 


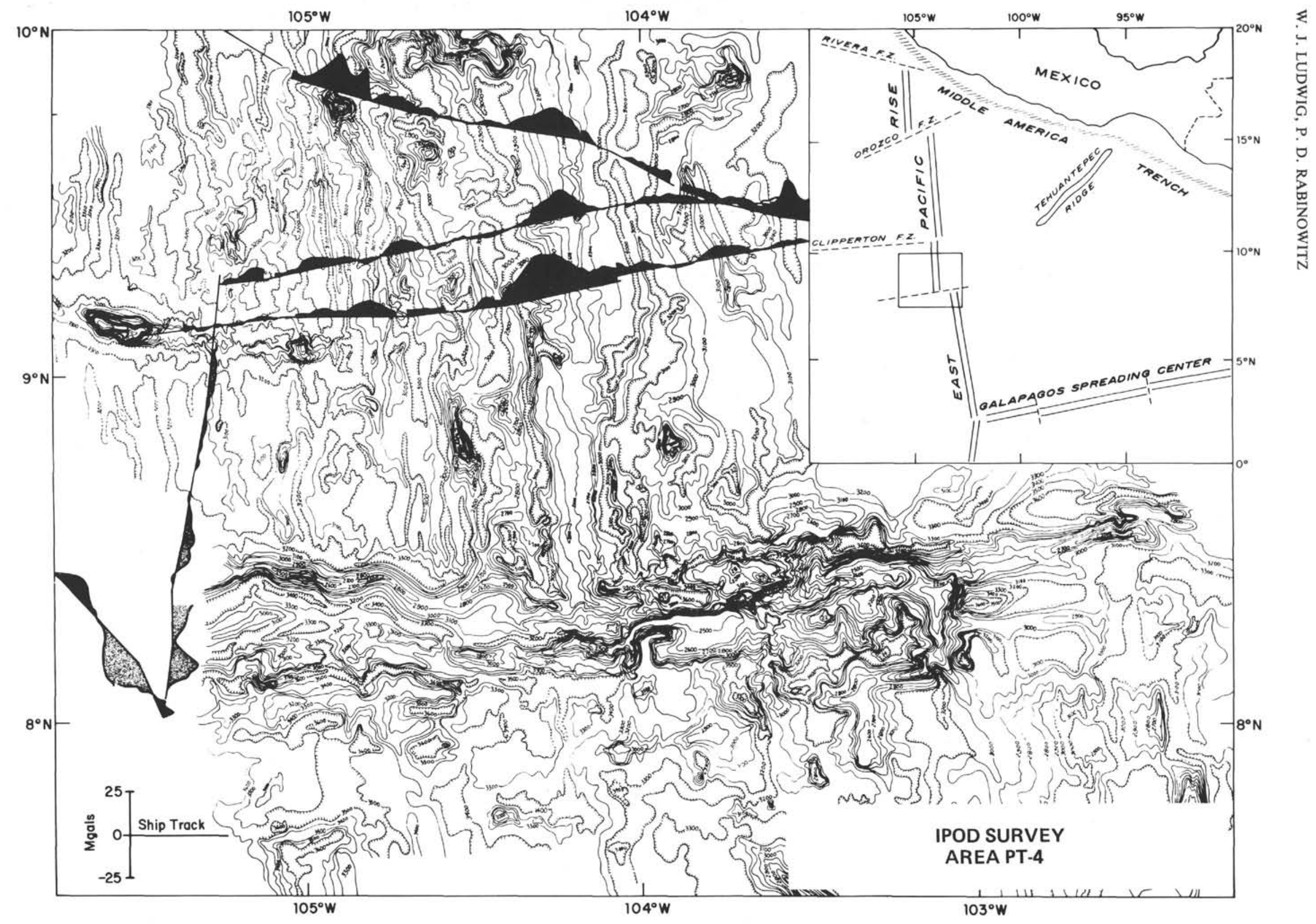

Figure 3. Free-air gravity anomaly profiles along ship tracks. IPOD Survey Area PT-4. Bathymetry contours from Rosendahl (this volume). 


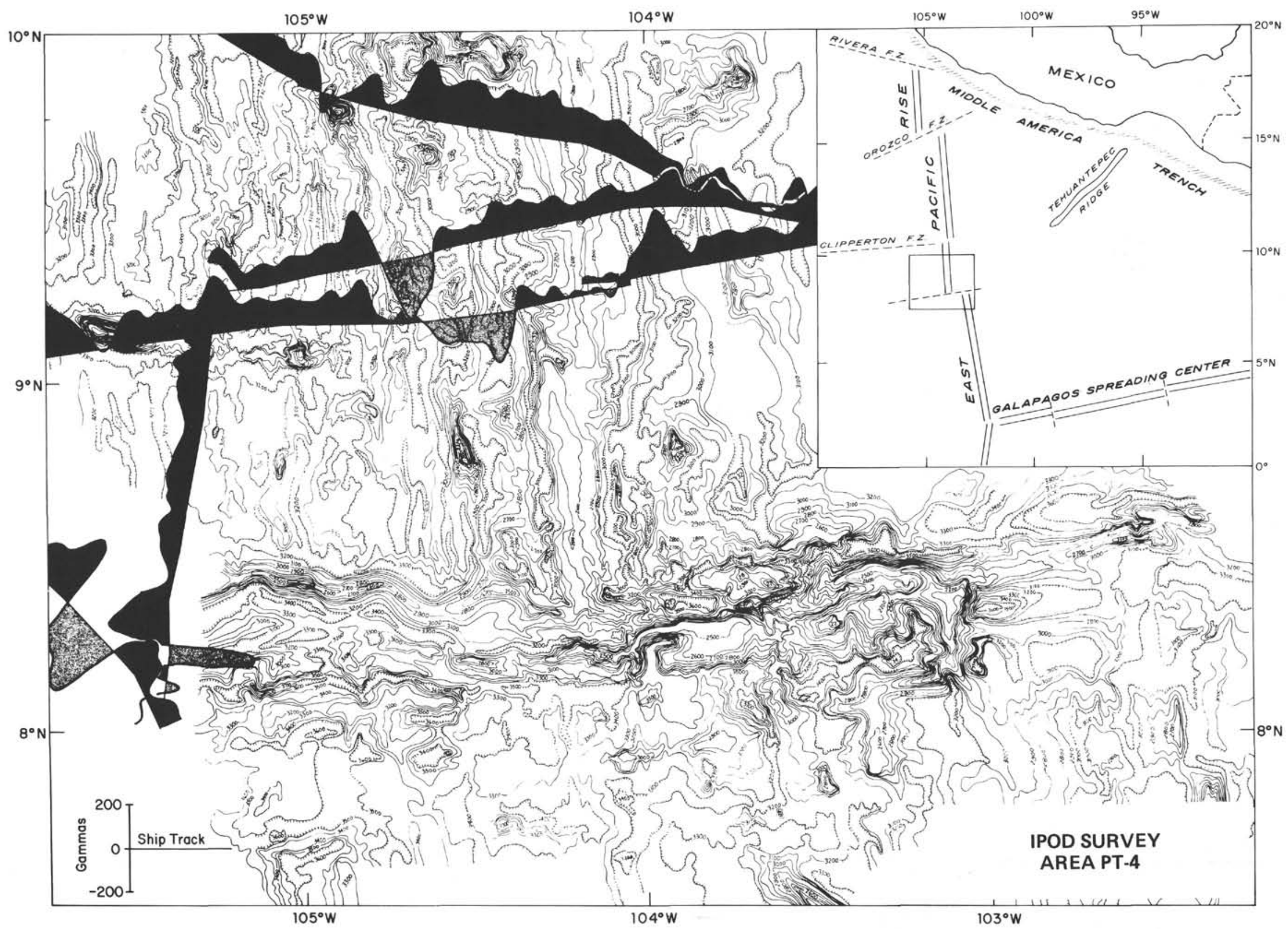

Figure 4. Magnetic anomaly profiles along ship tracks. IPOD Survey Area PT-4. Bathymetry from Rosendahl (this volume). 
W. J. LUDWIG, P. D. RABINOWITZ

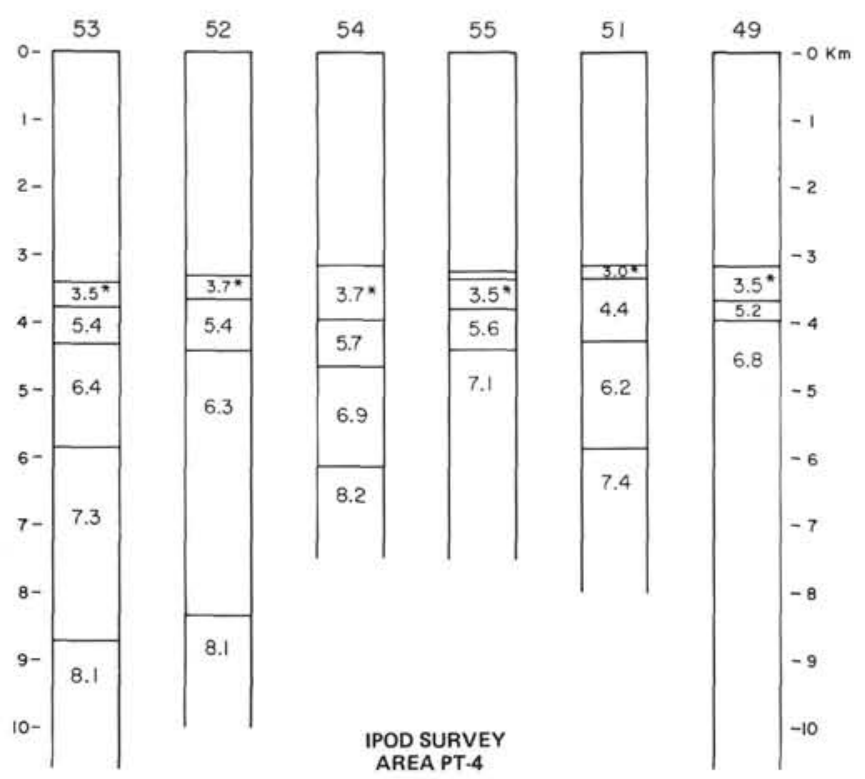

Figure 5. Airgun, sonobuoy solutions. IPOD Survey Area PT-4. Locations of sonobuoys given in Figure 1.

w

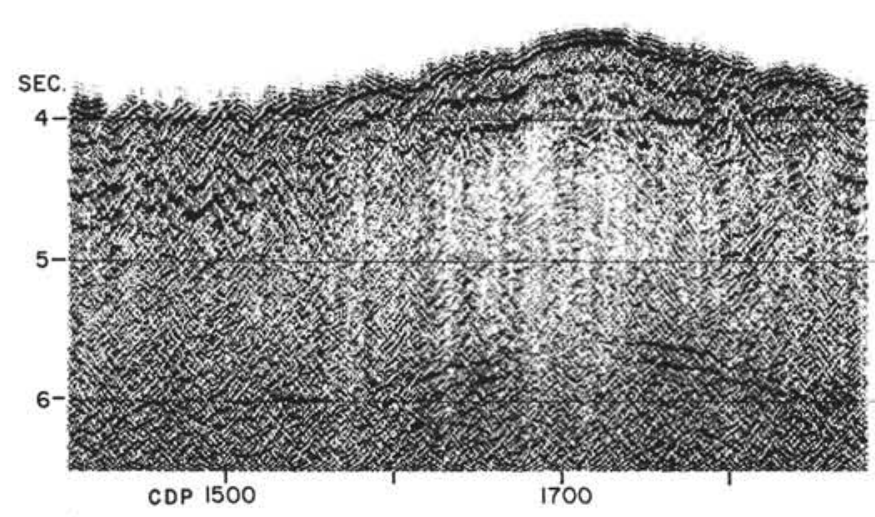

TIME ${ }^{\prime}$
RC 2002 MCS LINE 19

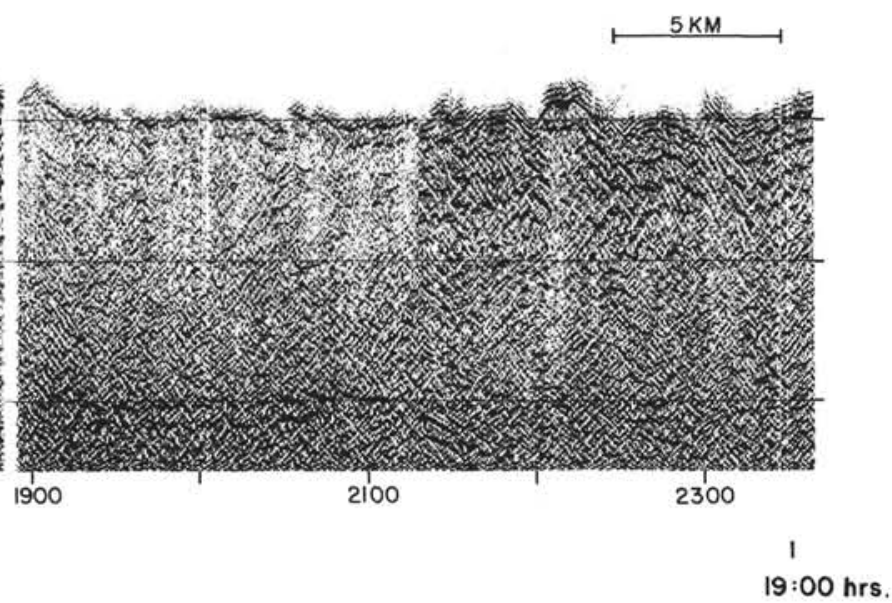

Figure 6. Migrated, common depth point (CDP), stacked time section 19 across the East Pacific Rise (EPR), from Stoffa et al. (in press). Note the distinct layering of the oceanic crust to about $0.8 \mathrm{~s}$ below the sea floor and the strong reflections from the top of mantle at about $6.0 \mathrm{~s}$ except in a $3-\mathrm{km}$ wide zone just to the west of the rise crest. Reflections from the top of seismic Layer 3, a strong refractor beneath the EPR and adjacent ocean basin, are not observed. The mantle reflections in this time section are conformable to the sea-floor topography, whereas in section $17,10 \mathrm{~km}$ to the south, they are observed at a fairly constant depth (see Stoffa et al., in press). The multichannel seismic data indicate that the low-velocity zone of low $\mathrm{Q}$ under the EPR crest, postulated by Orcutt et al. (1975, 1976) from $O B S$ data, may be a local feature and that discrete crustal layering occurs nearly contemporaneously with generation of ocean crust (see Herron et al., 1978; Stoffa et al., in press). 